\title{
Effects of NPK Fertilizer and Staking Methods on The Growth and Yield of Watermelon (Citrullus lanatus L.) in Unwana-Afikpo
}

\author{
I.O Oga ${ }^{1}$, P.N. Umekwe ${ }^{2}$ \\ Department of Agricultural Technology, Akanu Ibiam Federal Polytechnic, Unwana - Afikpo, P.M.B 1007, Afikpo, Ebonyi State, Nigeria
}

\begin{abstract}
An experiment was conducted at the Teaching, Demonstration and Research Farm of Department of Agricultural Technology, Akanu Ibiam Federal Polytechnic Unwana in Ebonyi State, to evaluate the effect of NPK fertilizer and staking methods on the growth and yield of watermelon (Citrullus lanatus L.). Three different rates of NPK fertilizer (0, 60 and $120 \mathrm{~kg} / \mathrm{ha})$ and two staking methods (staking and non-staking) were used. The experiment was conducted as $3 \times 2$ factorial laid out in Randomized Complete Block Design (RCBD) with four replications. The parameters assessed were: vine length, number of leaves, number of flowers, days to 50\% flowering, number of fruits, weight of fruits and number of marketable fruits. Treatment means were separated using least significant difference $(L S D=0.05)$. The result from this study showed that NPK fertilizer had a significant effect on the vine length, number of flowers, number of fruits and number of marketable fruits. The staked treatment constantly performed better with higher values than unstaked plants except in number of leaves and weight of fruits. Hence, for maximum production of watermelon, NPK fertilizer rates at $60 \mathrm{~kg} / \mathrm{ha}$ and staking should be adopted.
\end{abstract}

Keyword: Fertilizer, staking, watermelon, growth and yield

\section{Introduction}

Watermelon (Citrullus lanatus L.) is a vine-like flowering plant originated from South Central Africa. It is a member of the family; Cucurbitaceae, kingdom; plantae, order; cucurbitales, genus; Citrullus and specie; lanatus [1]. Watermelon refers to both fruit and plant of vine-like (climber or trailer) herb [2]. It is a tropical and sub-tropical plant and needs temperature higher than $25^{\circ} \mathrm{C}$. Seeds are usually sown on prepared beds, pots and then transplanted to a well drained sandy loam soil at a $\mathrm{pH}$ of 5.5 - 7 [3]. Watermelons have long prostrate vine growth and thus, require a lot of garden space for good yield [4]. The seeds of watermelon are rich in fat and protein and are consumed as snacks added to other dishes or used as an oil seed (Lawal, 2000). According to [5], watermelon is an unusual leading source of the carotenoid, lycopene and rich source of phenolic antioxidants. Watermelon responds positively to fertilizer application, the dosage depends on the soil type, climate and system of planting. Nitrogen under high temperature condition promotes maleness in flowering and lowers the number of females or perfect flowers, resulting in low fruit set [6]. A significant increase in vine length, number of leaves, leaf area and number of branches was recorded with increase in fertilizer application [3]. Similarly, [7] observed an increase in vine length, with an increase in nitrogen application. [8] noted that the response of Cucumber plants to NPK fertilizer at the rate of $150: 90: 90 \mathrm{~kg} /$ ha through fertigation gave maximum number of fruits per vine, weight of fruits $(\mathrm{g})$ and higher yield $(\mathrm{kg})$. [9] found that fertigation of $150 \mathrm{mgN} / \mathrm{L}$ gave the highest number of leaves, leaf area, fresh and dry weight of shoots and roots in Cucumber. [10] reported that NPK level at 120$90-60 \mathrm{~kg} / \mathrm{ha}$ significantly performed better with regards to head weight, diameter, length, marketable yield and head yield of Cabbage. [11] also reported that different dozes of NPK were significant different for days to flowering, days to fruiting, number of branches per plant, plant height $(\mathrm{cm})$, number of fruits per plant, length of fruit $(\mathrm{cm})$ and total yield $(\mathrm{kg} / \mathrm{ha})$. [7] reported that increasing the level of NPK resulted in a positive response in the vegetative growth and increased pod yield. Increase in nitrogen application lead to maximum length of fruit, weight of fruit, vine length and yield of Cucumber [12]. [13] reported that nitrogen application at $100 \mathrm{~kg} /$ ha significantly increased brinjal yield. Inspite of all these wonderful attributes of watermelon, the production of watermelon is still in the hands of peasant farmers in Nigeria who lack information in some important cultural practices such as staking for optimum yield of the crop. These farmers allow the vines to trail on the ground leading to the production of fruits with yellow bellies, overcrowding of vines and subsequently the attack by mould due to high humidity. Staking of watermelon shows enormous disparity and difference over unstaked one, as a result of avoiding competition, overcrowding and correct exposure or positioning of watermelon leaves to sunlight for effective photosynthetic activities that will enhance fruiting. $[14,15,16,17]$ observed that staked treatment gave higher yield than the unstaked treatment. The present study evaluated the effect of NPK fertilizer and staking methods on the growth and yield of watermelon (Citrullus lanatus L.) in Unwana-Afikpo.

\section{Materials and Methods}

The experiment was conducted at the Teaching, Demonstration and Research farm of Department of Agricultural Technology, Akanu Ibiam Federal Polytechnic Unwana-Afikpo, during 2014 rainy season. The experiment was conducted as $3 \times 2$ factorial laid out in Randomized Complete Block Design (RCBD) with four replications. Four levels of NPK fertilizer at 0,60 , and $120 \mathrm{~kg} / \mathrm{ha}$ with two staking methods (staking and non-staking) were combined into a total of six treatments combination. The variety used was sugar baby early mature within 70 to 75 days after planting. Seeds of watermelon were sown on flat

\section{Volume 4 Issue 12, December 2015}




\section{International Journal of Science and Research (IJSR) \\ ISSN (Online): 2319-7064}

Index Copernicus Value (2013): 6.14 | Impact Factor (2014): 5.611

bed of $2 \mathrm{~m} \times 2 \mathrm{~m}$. The different levels of fertilizer were applied at three weeks after planting. All cultural practices (i.e. weeding and crop protection) were carried out throughout the growing season as usually recommended. The parameters tested were - vine length, number of leaves, number of flowers, number of days to $50 \%$ anthesis, number of fruits, weight of fruits and number of marketable fruits at harvest. All recorded data were analyzed using the ANOVA technique and mean differences by the use of least significant difference (LSD) as described by Obi (2001).

\section{Results}

\subsection{Vine Length}

The result shown in Table 1 revealed that NPK fertilizer rates had significant effect on vine length. NPK fertilizer rates at $120 \mathrm{~kg} / \mathrm{ha}$ produced highest number of vine (74.82) while the shortest vine was recorded at control (64.33) and they differed significantly. Vine length recorded at $60 \mathrm{~kg} / \mathrm{ha}$ NPK and $120 \mathrm{~kg} /$ ha NPK were statistically similar. The Table also shows that vine lengths were not significantly affected by staking methods, though staked plants produced the longest vine than the unstaked plants. The interaction of NPK fertilizer and staking methods were significant at $\mathrm{P}=$ 0.05 (Table 1). Vine length obtained at $120 \mathrm{~kg} / \mathrm{ha}$ NPK on the staked treatment was significantly higher than all other treatment combinations.

Table 1: Effect of NPK fertilizer and Staking Methods on Vegetative Growth of Watermelon

\begin{tabular}{|l|c|c|c|c|}
\hline Treatments & $\begin{array}{c}\text { Vine } \\
\text { length }\end{array}$ & $\begin{array}{c}\text { Number of } \\
\text { leaves }\end{array}$ & $\begin{array}{c}\text { Number of } \\
\text { flowers }\end{array}$ & $\begin{array}{l}\text { Days to 50\% } \\
\text { flowering }\end{array}$ \\
\hline NPK (kg/ha) & & & & \\
0 & $64.33^{\mathrm{b}}$ & $17.48^{\mathrm{a}}$ & $11.08^{\mathrm{c}}$ & $38.80^{\mathrm{a}}$ \\
60 & $73.84^{\mathrm{a}}$ & $19.55^{\mathrm{a}}$ & $20.34^{\mathrm{a}}$ & $38.75^{\mathrm{a}}$ \\
120 & $74.82^{\mathrm{a}}$ & $18.66^{\mathrm{a}}$ & $17.11^{\mathrm{b}}$ & $39.04^{\mathrm{a}}$ \\
LS & $*$ & $\mathrm{NS}$ & $*$ & $\mathrm{NS}$ \\
LSD & 7.81 & - & 2.71 & - \\
Staking & & & & \\
Staked $\left(\mathrm{S}_{1}\right)$ & $71.04^{\mathrm{a}}$ & $17.48^{\mathrm{a}}$ & $16.88^{\mathrm{a}}$ & $39.45^{\mathrm{a}}$ \\
Unstaked $\left(\mathrm{S}_{0}\right)$ & $70.95^{\mathrm{a}}$ & $19.63^{\mathrm{a}}$ & $16.47^{\mathrm{a}}$ & $38.28^{\mathrm{a}}$ \\
LS & $\mathrm{NS}$ & $\mathrm{NS}$ & $\mathrm{NS}$ & $\mathrm{NS}$ \\
\hline
\end{tabular}

Means in the same column having the same letter (s) are not significantly different at $P=0.05 ; \quad L S=$ level of significant; LSD = least significant difference; $N S=$ Not significant; * = significant at $\mathbf{P}=\mathbf{0 . 0 5}$

\subsection{Number of Leaves}

The result in Table 1 revealed that NPK fertilizer had no significant effect on the number of leaves produced. The result also showed that application of $60 \mathrm{~kg} / \mathrm{ha}$ NPK was found to be higher in terms of number of leaves and all the rates were better than the control. However, there is no significant difference in staking method used, but unstaked treatment gave the highest number of leaves. NPK fertilizer rates at staking interaction were significant (Table 1). The highest number of leaves was obtained at $60 \mathrm{~kg} / \mathrm{ha}$ NPK on the unstaked treatment (20.63) while the lowest (16.74) was observed at control on the staked plants and they differed significantly.

\subsection{Number of Flowers}

In Table 1, the result showed that there is significant difference on the number of flowers produced, $60 \mathrm{~kg} / \mathrm{ha}$ NPK fertilizer produced the highest number of flowers (20.34) while the least (11.08) was at control. Staked treatment produced the highest number of flowers than unstaked plants. NPK fertilizer rates at staking interaction were significant (Table 1). Number of flowers obtained at $60 \mathrm{~kg} / \mathrm{ha}$ NPK on the staked treatment was significantly higher than all other treatment combinations. The highest number of flowers was produced at $60 \mathrm{~kg} / \mathrm{ha} \mathrm{NPK}$ on the staked treatment (22.42) while the lowest was at control on the staked treatment (10.97) and they differed significantly.

\subsection{Days to $50 \%$ Flowering}

There is no significant difference in the effect of NPK fertilizer at days to $50 \%$ flowering of watermelon. Although, $120 \mathrm{~kg} / \mathrm{ha}$ NPK had the longest number of (39.04) days to $50 \%$ flowering while the shortest (38.75) days was at $60 \mathrm{~kg} / \mathrm{ha}$ NPK. There is no significant difference noticed with respect to staking methods (Table 1).

Table 2: Effect of NPK fertilizer and Staking Methods on the Yield of Watermelon

\begin{tabular}{|c|c|c|c|}
\hline $\begin{array}{l}\text { Treatments } \\
\text { NPK (kg/ha) }\end{array}$ & Number fruits & $\begin{array}{c}\text { Weight of } \\
\text { fruits }\end{array}$ & $\begin{array}{l}\text { Number of } \\
\text { marketable fruits }\end{array}$ \\
\hline 0 & $3.82^{\mathrm{b}}$ & $0.44^{2}$ & $2.49^{\circ}$ \\
\hline 60 & $5.66^{\mathrm{a}}$ & $0.48^{\mathrm{a}}$ & $3.76^{\mathrm{a}}$ \\
\hline 120 & $5.25^{\mathrm{a}}$ & $0.45^{\mathrm{a}}$ & $3.31^{\mathrm{a}}$ \\
\hline LS & * & NS & $*$ \\
\hline $\begin{array}{l}\text { LSD } \\
\text { Staking }\end{array}$ & 0.85 & - & 0.79 \\
\hline Staked $\left(\mathrm{S}_{1}\right)$ & $5.25^{\mathrm{a}}$ & $0.45^{\mathrm{a}}$ & $3.58^{\mathrm{a}}$ \\
\hline Unstaked $\left(\mathrm{S}_{0}\right)$ & $4.56^{b}$ & $0.46^{\mathrm{a}}$ & $2.79^{\circ}$ \\
\hline LS & * & NS & * \\
\hline LSD & 0.70 & - & 0.19 \\
\hline
\end{tabular}

Means in the same column having the same letter (s) are not significantly different at $P=0.05 ; L S=$ level of significant; LSD = least significant difference; $N S=$ Not significant; * = significant at $\mathbf{P}=\mathbf{0 . 0 5}$

\subsection{Number of fruits}

NPK fertilizer had significant effect on number of fruits produced (Table 2). Maximum number of fruits (5.66) was recorded at $60 \mathrm{~kg} / \mathrm{ha}$ NPK while the minimum (3.82) was at control and they differed significantly. Staking had a significant effect on the number of fruits. Staked treatment produced the higher number of fruits than the unstaked treatment (Table 2).

\section{Volume 4 Issue 12, December 2015}




\subsection{Weight of fruits}

The result in Table 2 revealed that there is no significant difference among the rates of fertilizer used. However, all the rates were better than the control. Moreover, no significant difference was recorded with respect to staking methods. The interaction of NPK fertilizer and staking on the yield of watermelon had no significant effect. The highest weight of fruits $(0.50 \mathrm{~kg})$ was obtained from the combination of $60 \mathrm{~kg} / \mathrm{ha}$ NPK with unstaked and lowest weight $(0.44 \mathrm{~kg})$ from the combination of control with unstaked treatment (Table 2).

\subsection{Number of marketable fruits}

NPK fertilizer rates and staking methods had significant effect on the number of marketable fruits at $\mathrm{P}=0.05$ (Table $2)$. The highest number of marketable fruits was obtained at $60 \mathrm{~kg} / \mathrm{ha}(3.76)$ while the lowest was recorded at control (2.49) and they differed significantly. However, staked plants produced the highest number of marketable fruits than the unstaked treatment and they differed significantly.

Table 3: An Interaction between NPK fertilizer and Staking Methods on the Growth and Yield of Watermelon

\begin{tabular}{|l|c|c|c|c|c|c|c|}
\hline Treatments & $\begin{array}{c}\text { Vine } \\
\text { length }\end{array}$ & $\begin{array}{c}\text { Number of } \\
\text { leaves }\end{array}$ & $\begin{array}{c}\text { Number of } \\
\text { flowers }\end{array}$ & $\begin{array}{c}\text { Days to 50\% } \\
\text { flowering }\end{array}$ & $\begin{array}{c}\text { Number of } \\
\text { fruits }\end{array}$ & $\begin{array}{c}\text { Weight of } \\
\text { fruits }\end{array}$ & $\begin{array}{c}\text { Marketable } \\
\text { fruits }\end{array}$ \\
$0 / \mathrm{S}_{1}$ & $62.16^{\mathrm{a}}$ & $16.74^{\mathrm{c}}$ & $10.97^{\mathrm{e}}$ & $39.50^{\mathrm{a}}$ & $3.88^{\mathrm{a}}$ & $0.44^{\mathrm{a}}$ & $2.79^{\mathrm{a}}$ \\
$0 / \mathrm{S}_{0}$ & $66.49^{\mathrm{d}}$ & $18.21^{\mathrm{b}}$ & $12.18^{\mathrm{d}}$ & $38.09^{\mathrm{a}}$ & $3.75^{\mathrm{a}}$ & $0.43^{\mathrm{a}}$ & $2.19^{\mathrm{a}}$ \\
$60 / \mathrm{S}_{1}$ & $70.97^{\mathrm{e}}$ & $18.46^{\mathrm{b}}$ & $22.42^{\mathrm{a}}$ & $39.50^{\mathrm{a}}$ & $5.94^{\mathrm{a}}$ & $0.46^{\mathrm{a}}$ & $3.96^{\mathrm{a}}$ \\
$60 / \mathrm{S}_{0}$ & $76.71^{\mathrm{b}}$ & $20.63^{\mathrm{a}}$ & $19.26^{\mathrm{b}}$ & $38.00^{\mathrm{a}}$ & $5.38^{\mathrm{a}}$ & $0.50^{\mathrm{a}}$ & $3.56^{\mathrm{a}}$ \\
$120 / \mathrm{S}_{1}$ & $79.99^{\mathrm{a}}$ & $17.25^{\mathrm{b}}$ & $17.25^{\mathrm{e}}$ & $39.34^{\mathrm{a}}$ & $5.94^{\mathrm{a}}$ & $0.45^{\mathrm{a}}$ & $4.00^{\mathrm{a}}$ \\
$120 / \mathrm{S}_{0}$ & $69.65^{\mathrm{d}}$ & $20.06^{\mathrm{a}}$ & $17.96^{\mathrm{c}}$ & $38.75^{\mathrm{a}}$ & $4.56^{\mathrm{a}}$ & $0.45^{\mathrm{a}}$ & $2.62^{\mathrm{a}}$ \\
$\mathrm{LSD}$ & 3.23 & 1.45 & 1.09 & $\mathrm{NS}$ & NS & NS & NS \\
\hline
\end{tabular}

Means in the same column having the same letter (s) are not significantly different at $P=0.05$; $L S D=$ least significant difference and NS = Not significant

\section{Discussion}

\subsection{Vegetative Growth}

The result of this field trial showed that NPK fertilizer had a significant effect on the vine length and number of flowers and $120 \mathrm{~kg} / \mathrm{ha}$ NPK produced the longest vine and this is in conformity with work done by $[12,7]$ who reported that an increase in vine length of watermelon was recorded with an increase in nitrogen application. The application of $60 \mathrm{~kg} / \mathrm{ha}$ NPK produced the highest number of leaves and number of flowers. This is in agreement with the work done by [3] who reported that a significant increase in number of leaves, leaf area, and branches was recorded with increase in fertilizer application. The study further revealed that the number of flowers was affected by the fertilizer application and this may be attributed to increase in vegetative growth. This is in accordance with the findings of [19] who reported that an increase in fertilizer application increases the flowering of watermelon. The number of days to $50 \%$ flowering was longest at $120 \mathrm{~kg} / \mathrm{ha}$ NPK and shortest at $60 \mathrm{~kg} / \mathrm{ha}$ NPK. This is not in conformity with the report by [20] who observed that NPK application rates of 60,140 and $150 \mathrm{~kg} / \mathrm{ha}$ delayed number of days to flowering, fruit setting and maturity of watermelon.

Staked plants produced the longest vine and number of days to $50 \%$ anthesis while unstaked plants produced the highest number of leaves and number of flowers. The unstaked plants had an early bud break than staked treatment.

\subsection{Yield}

It was observed that $60 \mathrm{~kg} / \mathrm{ha}$ NPK fertilizer rates produced the highest values in all the yield parameters assessed.
Proper nutrients promote vigorous growth of watermelon plant, which in turn increases the number of fruits which confirm the observation of [21] for cucumber when $80 \mathrm{~kg} / \mathrm{ha}$ nitrogen was applied. The yield parameters assessed were found to be higher on the staked treatment than that vine on the ground. The result agreed with the findings of [15] who observed that the yield of super select Cucumber was higher for the trellised treatment than for the non-trellised treatment. They also affirmed that staking improves the colour and lower the incidence of yellow bellies in watermelon.

\section{Conclusion}

From the above discussions, it could be concluded that there was a significant increase in vine length, number of flowers, number of fruits and number of marketable fruits of watermelon as a result of NPK fertilizer application at the rate of $60 \mathrm{~kg} / \mathrm{ha}$ except in vine length. It is important to state here that NPK fertilizer and staking at $60 \mathrm{~kg} / \mathrm{ha}$ with staking showed better performance than other NPK fertilizer rates and staking methods. Following this, NPK fertilizer and staking at $60 \mathrm{~kg} / \mathrm{ha}$ is recommended to farmers in the study area for a more profitable production of watermelon.

\section{References}

[1] Wikipedia Free encyclopedia. 2013; Http://en.wikipedia.org/w/index

[2] Thulaja NR Watermelon, National Library Board, Singapore North Carilina University. Watermelon, a paper presented at chapel hill.2005.

[3] Lawal AB Response of cucumber to intercropping with maize and varying rates of farmyard manure an 
inorganic fertilizer Agricultural and Environment. 2000; 2(1):78 - 83 .

[4] George A Horticulture, principles and practice, second edition. 2004.

[5] World healthiest foods. www.wh food.com 2013

[6] Chadha KL, Eldesuki RM, Salman SR and Hussein SD Performance of some Snap bean varieties as affected by different levels of mineral fertilizers, J. Agron. 2005; 4:242-247.

[7] Abdel-Mawgoud AMR, El-Desuki M, Salman SR and Husein SDA Performance of some snap bean varieties as affected by different levels of mineral fertilizers. $J$. Agron. 2005; 4:242 - 247.

[8] Choudhari SM and More TA Fertigation, fertilizer and spacing requirement of tropical gynoecious cucumber hybrids. ISHS. Tsukuba, Japan. Acta Hort. 2002; 61:588.

[9] Watcharasak $\mathrm{S}$ and Thammasak $\mathrm{T}$ Effect of nitrogen and potassium concentration in fertigation on growth and yield of cucumber. Kamphaengsaen Acad. J. 2005; 3:18 - 29.

[10] Din M, Qasim M and Alam M Effect of different levels of $\mathrm{N}, \mathrm{P}$ and $\mathrm{K}$ on the growth and yield of cabbage. $J$. Agric. Res. 2007; 45:171 - 176.

[11] Naeem N, Irfan M, Khan J, Nabi G., Muhammad N. and Badshah N Influence of various levels of nitrogen and phosphorus on growth and yield of chilli (Capsicum annum L.). Asian J. Plant Sci. 2002; 1:599 - 601.

[12] Ahmed N, Baloch MH, Haleem A, Ejaz M and Ahmed $\mathrm{N}$ Effect of different levels of nitrogen on the growth and production of cucumber. Life Sci. Int. J. 2007; 1:99 $-102$.

[13] Jilani MS, Afzaal MF and Waseem K Effect of different nitrogen levels on growth and yield of brinjal. J. Agric. Res. 2008; 46:245 - 251.

[14] Hirata,SL and Tilato R Comparative cost of teepeetrellised vs non-trellised cucumber production. Economics Information Report. 2002; pp40 -46.

[15] Hardy C. and Rowell B Trellising slicing cucumber in western Kenturkey. Hort. Bulleting. 2002; 3:15 - 318.

[16] Paulo So Lina S, Jauton FR, Jaedson CAM and Jaevason DAS Plant density and fruit density of muskmelon. Rer. Bras frustic. 2003; 25:22.

[17] Nelson H Effect of population density on fruits and seeds production in Muskmelon Acta Horticulture. 2005; 38(3): 15 - 28.

[18] Obi IU Fixed and Random Treatment Models in Analysis of Variance for Balance Design. Department of Crop Science, University of Nigeria, Nsukka. Star Print and Publishing Co, Enugu, Nigeria. 2001; 38pp.

[19]Efediyi EK and Samaon UR Effect of inorganic fertilizer on the yield of two varieties of cucumber (Cucumis sativus L.). Report and Opinion. 2009; 5:7479

[20] Rehman HU, Jilani MS, Munir M and Ghafoor A Effect of different levels of NPK on the performance of three varieties of cucumber. Gomal University J. Res. 1995; 15:125 - 133 .

[21] Waseem K, Kamran QM and Jilani MS Effect of different levels of nitrogen on the growth and yield of cucumber (Cucumis sativus L.). J. Agric. Res. 2008; $46: 259$ - 266. 